Adıyaman Üniversitesi Sağlık Bilimleri Dergisi, 2020;6(3):332-337

doi:10.30569.adiyamansaglik.770746

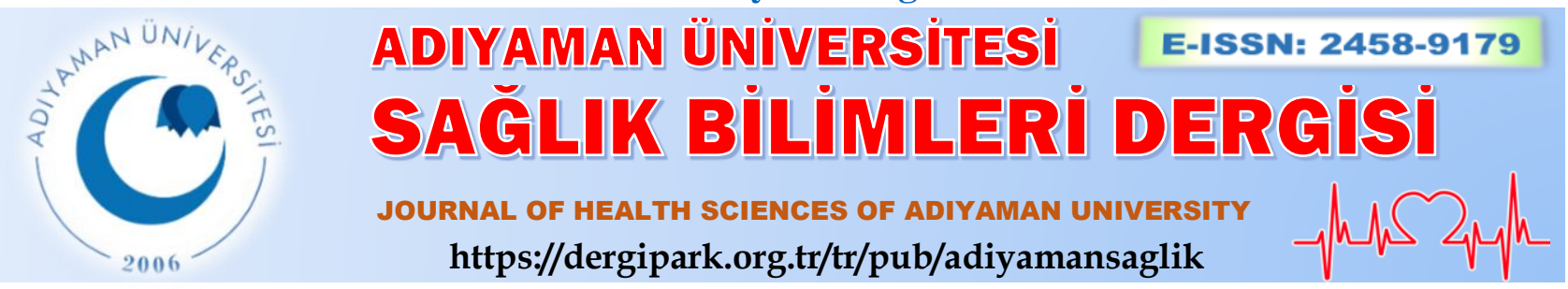

Özgün Araştırma/Research Article

\title{
Bir doğum hastanesinde HBsAg tarama testi ve Hepatit B'yi önleme uygulamalarının değerlendirilmesi
}

\section{Evaluation of HBsAg test and Hepatitis B prevention practices in a maternity hospital}

\author{
Burcu BEYAZGÜL ${ }^{1 @(D), ~ E n g i n ~ O ̈ Z T U ̈ R K ~}{ }^{(D)}$, İbrahim KORUK ${ }^{1}$ (D), Fatma KORUK ${ }^{3}$ (D) \\ ${ }^{1}$ Harran Üniversitesi, Tıp Fakültesi, Halk Sağlığı Anabilim Dalı, 63290, Şanlıurfa-Türkiye \\ ${ }^{2}$ Şanlıurfa Eğitim Araştırma Hastanesi, Kadın Hastalıkları ve Doğum Anabilim Dalı, 63250, Şanlıurfa-Türkiye \\ ${ }^{3}$ Harran Üniversitesi, Sağlık Bilimleri Fakültesi, 63000, Şanlıurfa-Türkiye
}

Atıf gösterme/Cite this article as: Beyazgül B, Öztürk E, Koruk İ, Koruk F. Bir doğum hastanesinde HBsAg tarama testi ve Hepatit B'yi önleme uygulamalarının değerlendirilmesi. ADYÜ Sağlık Bilimleri Derg. 2020;6(3):332-337. doi:10.30569.adiyamansaglik. 770746

\section{Öz}

Amaç: Şanlıurfa'da bir doğum hastanesinde gebelerde HBsAg tarama yapılma düzeyi, Hepatit B taşıyıcı annenin yenidoğanına yönelik Hepatit B aşısı ve HIBG uygulama düzeyleri ile bunlarda 2008 yılına göre oluşan değişimin değerlendirilmesi amaçlanmaktadır.

Gereç ve Yöntem: Şanlıurfa'da Eğitim ve Araştırma Hastanesinde takip edilen gebeler üzerinde yürütülmüştür. Çalışma için hastanenin 2019 y1lı verileri kullanılmıştır.

Bulgular: Hastaneye 2019 yılı içerisinde başvuran toplam gebe sayıs1 55073'tür. 2008 ile 2019 yılları arasında doğum sonrası yenidoğana HBIG uygulama durumu \%59,1'den \%100,0'e, Hepatit B aşıs1 uygulanma durumu \%88,7'den \%100,0'e yükselmiştir $(p<0,05)$.

Sonuç: Gebelerde HBsAg pozitiflik düzeylerinde azalma olduğuna işaret etmektedir.

Anahtar Kelimeler: Gebe; Hepatit B; HBsAg tarama; Hepatit B aşısı.

\begin{abstract}
Aim: It is aimed to evaluate the level of $\mathrm{HBsAg}$ screening in pregnant women in a maternity hospital in Şanlıurfa, Hepatitis B vaccine and HIBG application levels for the newborn of the hepatitis B surrogate mother, and the change in these according to 2008.

Materials and Methods: It was conducted on the pregnant women who were followed up in the Training and Research Hospital in Şanliurfa.2019 data of the hospital was used for the study.

Results: The total number of pregnant women admitted to the hospital in 2019 is 55073. Between 2008 and 2019, the application of HBIG to newborns after birth increased from $59.1 \%$ to $100.0 \%$, and Hepatitis B vaccine increased from $88.7 \%$ to $100.0 \%$ $(p<0.05)$.
\end{abstract}

Conclusion: It indicates a decrease in $\mathrm{HBsAg}$ positivity levels in pregnant women.

Keywords: Pregnant; hepatitis B; HBsAg screening; Hepatitis B vaccine.

Yazışma Adresi/Address for Correspondence: Burcu BEYAZGÜL, Harran Üniversitesi, Tıp Fakültesi, Halk Sağlığı Anabilim Dal1, 63290, Şanlıurfa-Türkiye, E-mail: brckara86@ hotmail.com

Geliş Tarihi/Received:17.07.2020 Kabul Tarihi/Accepted:06.11.2020

Yayım Tarihi/Published online:03.12.2020

Bu eser, Creative Commons Atıf-GayriTicari 4.0 Uluslararası Lisansı ile lisanslanmıștır. Telif Hakkı @ 2020 Adıyaman Üniversitesi Rektörlüğü 


\section{Giriş}

Dünya genelinde yaklaşı 325 milyon Hepatit $\mathrm{B} / \mathrm{C}$ virüsü ile enfekte kişi olduğu ve bunun da 257 milyonunun Hepatit B ile enfekte olduğu tahmin edilmektedir. Ancak, DSÖ'nün bildirdiğine göre, Hepatit $\mathrm{B}$ ile enfekte kişilerin sadece \%10,5'i (27 milyon) enfeksiyon durumunu bilmektedir. ${ }^{1} 2015$ y1lında Hepatit B virüs enfeksiyonundan kaynaklanan çoğunluğu siroz ve karaciğer kanserine bağlı 887.000 ölüm vakası olduğu tahmin edilmektedir. Hepatit $\mathrm{B}$ virüsünün akut ve kronik hepatit, karaciğer yetmezliği, siroz, karaciğer kanseri gibi potansiyel sonuçları düşünüldügünde önemli bir halk sağlığ 1 sorunu olarak belirtilmektedir. ${ }^{2}$

Türkiye'de yaşayan 18 yaş üstü her üç kişiden birinin Hepatit $\mathrm{B}$ ile karşılaştı̆̆ 1 tahmin edilmektedir. $\mathrm{Bu}$ durum alınmas1 gereken önlemlerin önemini ortaya koymaktadır. Türkiye genelinde erişkinlerde Hepatit B surface antijen (HBsAg) pozitifliği 2009 y1linda $\% 4,0$ ve gebelerde $\% 1,6$ olarak bildirilmiştir. ${ }^{3,4}$ Şanlıurfa'da ise 2008 yılında toplumda $\% 4,2$ ve gebelerde $\% 4,7$ olarak bildirilmektedir. ${ }^{5,6}$

Hepatit B virüsü cinsel yolla, anneden bebeğe perinatal geçiş (vertikal geçiş), kan ve vücut sivilarıyla temas yoluyla, enfekte kişilerle cinsel olmayan yakınlık sonucu oluşan horizontal geçiş ile bulaşabilmektedir. ${ }^{7}$ Hepatit B virüsü ile yetişkin dönemde enfekte olunduğunda kronikleşme olasıllğ $1 \% 5$ 'ten az olmasına rağmen, bebeklik ve erken çocukluk dönemindeki karşılaşmalarda kronikleşme \%95'lere yükselmektedir. Dolayısı ile bu seyir perinatal geçişi önlemeye yönelik çalışmaları ve çocukluk dönemi müdahalelerini daha da önemli hale getirmektedir. $^{2}$

Türkiye'de, Hepatit B aşısı 1998'de çocukluk çağı aşı takvimine girmiş ve $\mathrm{o}$ tarihten itibaren 3 doz olarak uygulanmaya başlamıştır. Aşının ilk dozu 1998-2001 arasında doğumdan sonra 2. ayın sonunda yapılmakta iken 2003'ten itibaren doğumda uygulanmaya başlanmıştır. ${ }^{8,9}$

Hastalıklardan Koruma ve Kontrol Merkezi (Center for Disease Prevention and Control, CDC) 1984 y1lından itibaren Hepatit
B'nin konjenital geçişini önlemek amacıyla tüm gebelerin HBsAg yönünden taranmasını ve pozitif gebeden doğan yenidoğana Hepatit B aşıs1 ile birlikte Hepatit B Hiperimmunglobulini (HBIG) uygulanmasını önermektedir. $^{10}$ Türkiye'de, 2002 yılında başlatılan Hepatit B Kontrol Programı ile, tüm yenidoğanlara ilk 72 saat içerisinde Hepatit B aşısı uygulanması ve Hepatit $B$ taşıyıcısı gebelerin yenidoğanlarına 12 saat içinde aşı ile birlikte HBIG uygulanması ilk kez gündeme alınmıştır. ${ }^{9}$ Daha sonra Ana-Çocuk Sağlığı ve Aile Planlaması Genel Müdürlüğü tarafından 2010 yilında hazırlanan Doğum Öncesi Bakım Yönetim Rehberi ile HBsAg testi ile tüm gebelerin taranmasi zorunlu hale getirilmiştir. 2,8,11 Hepatit B Kontrol Programı, 2018 yılında Türkiye Viral Hepatit Önleme ve Kontrol Programı 2018-2023 olarak güncellenmiş bir önceki programda belirtilen faaliyetlere ilaveten viral yükü yüksek gebelere tedavi verilmesi ve doğum sonu izlemlerinin güçlendirilmesi gerektiği vurgulanmıştır. 9

Bölgedeki kadınların \%25'i hiç okula gitmemiş ya da ilkokulu bitirmemiştir. Kadınların yalnızca \%17'si gelir getiren bir işte çalışmaktadır. Son gebeliğinde doğum öncesi bakım hizmetinden yararlanma $\% 96$ ve bir sağlik kuruluşunda doğum yapma \%97,6'dır. ${ }^{12}$ Türkiye İstatistik Kurumu'nun 2018 y1lı verilerine göre Şanlıurfa'da toplam doğurganlık hızı 4,13, kaba doğum hızı binde 31,3 'tür. ${ }^{13}$

$\mathrm{Bu}$ çalışmada Şanlıurfa'da bir doğum hastanesinde gebelerde HBsAg tarama yapılma düzeyi, Hepatit $\mathrm{B}$ taşıyıcı annenin yenidoğanına yönelik Hepatit $B$ aşısı ve HIBG uygulama düzeyleri ile bunlarda 2008 yılına göre oluşan değişimin değerlendirilmesi amaçlanmaktadır.

\section{Gereç ve Yöntem}

\section{Araştırmanın tipi}

Bu çalışma kesitsel tiptedir.

\section{Araştırmanın evreni ve örneklemi}

Çalışma Güneydoğu Anadolu Bölgesi'nde bulunan Şanlıurfa ilinde yapılmıştır. Çalışma, Şanlıurfa'da Eğitim ve Araştırma Hastanesinde yürütülmüştür. Kadın 
Hastalıkları ve Doğum Hastanesi 2016 tarihine kadar hizmet vermiştir. Bu tarihten sonra ise, Sanlıurfa'da Eğitim ve Araştırma Hastanesi bünyesinde bir bölüm olarak çalışmalarını sürdürmektedir. Çalışmanın evrenini 2019 yılında Şanlıurfa'da Eğitim ve Araştırma Hastanesi'nde takip edilen gebeler oluşturmaktadır. Örnek seçilmemiş olup, tüm başvuranlar çalışmaya dahil edilmiştir.

\section{Veri toplama araçları}

Çalışma için hastanenin 2019 yılına ait sağlık kayıtları kullanılmıştır. Hastaneye başvuran toplam gebe sayıs1, HBsAg testi yapılan gebe sayıs1, HBsAg pozitif gebe sayıs1, hastanede doğum yapan gebe sayısı, doğum sonrası bebeğe HBIG uygulanma sayıs1 ve doğum sonrası bebeğe Hepatit B aşısı uygulanma sayısına ilişkin veriler hastane kayıtlarından sağlanmıştır.

2019 yllında Şanlıurfa'da Eğitim ve Araştırma Hastanesi'nde takip edilen gebelerin verileri, 2008 yılında Şanlıurfa Kadın Hastalıkları ve Doğum Hastanesinde bir müdahale çalışması sonrası elde edilen aynı verilerle karşılaştırılmıştır. 2008 yılında yapılan çalışmanın sonuçları, HBsAg testi uygulanmasını, doğum sonrası hepatit B aşısı ve HBIG uygulamalarını arttırmaya yönelik bir dizi müdahaleler sonrasında elde edilmiştir. $^{5}$

\section{Verilerin analizi}

Çalışma verilerinin analizi için SPSS 20 paket programı kullanılmıştır. Verilerin tanımlayıc1 istatistikleri yüzde ile verilmiş, tek değişkenli analizler ki kare testi ile yapılmıştır.

\section{Araştırmanın etik boyutu}

Çalışma için, İlgili Üniversitenin Tıp Fakültesinin Etik Kurulu'ndan ve verilerin toplandığı hastaneden yazılı izni alınmıştır. Helsinki İlkeler Deklarasyonuna uygun olarak çalışılmıştır.

\section{Bulgular}

Hastaneye 2019 yılı içerisinde başvuran toplam gebe sayis1 55073'tür. Gebelerin $\% 80,8$ 'ine HBsAg testi istenmiş olup, \%1,4'ünde HBsAg pozitif bulunmuştur (Tablo 1).

Tablo 1. Hastaneye başvuran gebelerden HBsAg testi istenme durumu.

\begin{tabular}{lcc}
\hline & Sayı (n) & Yüzde (\%) \\
\hline $\begin{array}{l}\text { HBsAg testi uygulanan } \\
\text { gebe sayısı }\end{array}$ & 44523 & 80,8 \\
$\begin{array}{l}\text { HBsAg pozitif gebe } \\
\text { sayıs1 }\end{array}$ & 643 & 1,4 \\
\hline $\begin{array}{l}\text { Hastaneye başvuran } \\
\text { toplam gebe sayısı }\end{array}$ & 55073 & 100,0 \\
\hline
\end{tabular}

Hastanede doğan bebekleri Hepatit B'den korumak için yapılan müdahaleler Tablo 2'de gösterilmektedir. Hastanede doğum yapan gebe sayıs1 32082 olup, tümüne HBsAg testi yapılmıştır. Doğum yapan gebelerin içinde HBsAg testi pozitif olanlar \%1,2'dir. HBsAg testi pozitif olan gebeden doğan 378 bebekten 327 'sine $(\% 86,5)$ HBIG ve Hepatit B aşısı uygulanmıştır. HBsAg testi pozitif olan gebeden doğan 14 ex fetüse ve 34 . gestasyonel haftadan önce doğduğu için dış merkeze sevk edilen 37 bebeğe HBIG ve Hepatit B aşısı uygulanamamıştır $(\% 13,5)$. HBsAg testi negatif olan gebeden doğan 31704 bebekten 30946'sina $(\% 96,5)$ Hepatit B aşısı uygulanmıştır. HBsAg negatif gebeden doğan 116 ex fetüse, 34. gestasyonel haftadan önce doğduğu için diş merkeze sevk edilen 114 bebeğe, hastanenin yenidoğan yoğun bakımına yatırılan ve doğum ağırlığı 2000 gramın altında olan 528 bebeğe Hepatit $\mathrm{B}$ aşısı uygulanamamıştır $(\% 3,5)$.

Tablo 2. Hastanede doğan bebeklere yapılan hepatit B'den koruyucu müdahaleler.

\begin{tabular}{ccc}
\hline & Sayı (n)* & Yüzde (\%) \\
\hline Doğum yapan gebelere HBsAg testi yapılma sayısı & 32082 & 100,0 \\
Doğum yapan gebelerden HBsAg testi pozitif olanların sayısı & 378 & 1,2 \\
Doğum sonrası HBIG uygulanan bebek sayısı & 327 & 1,0 \\
Doğum sonrası Hepatit B aşısı uygulanan bebek sayısı & 327 & 1,0 \\
Doğum yapan gebelerin içinde HBsAg testi negatiflerin sayısı & 31704 & 98,8 \\
Doğum sonrası Hepatit B aşısı uygulanan bebek sayısı & 30946 & 96,5 \\
\hline
\end{tabular}

* Hastanede doğum yapan toplam gebe sayısı 32082'dir 
Gebelere HBsAg testi yapılma durumu, yapılan test sonuçlarına göre HBsAg durumu, doğum sonu yenidoğana HBIG ve Hepatit B aşıs1 uygulanma durumuna ilişkin veriler, aynı hastanede 2008 yılında yapılan araştırmanın verileri ile karşılaştırılarak Tablo 3 'de verilmiştir. HBsAg testi yapılma durumu 2008 yılında müdahale sonrası \%99,9 iken 2019 yilında \%100,0 olmuştur $(p<0,05)$.
HBsAg pozitiflerin düzeyi 2008 y1lında $\% 4,7$ iken 2019 yılında \%1,2'ye gerilemiştir $(p<0,05)$. Doğum sonrası yenidoğana HBIG uygulama durumu 2008 yilında müdahale sonras1 \%59,1 iken 2019 y1lında \%100,0 olmuştur $\quad(p<0,05)$. Doğum sonrası yenidoğana Hepatit $\mathrm{B}$ aşısı uygulanma durumu 2008 yılında \%88,7 iken 2019 yılında $\% 100,0$ olmuştur $(p<0,05)$.

Tablo 3. HBsAg testi yapılma, HBsAg durumu ve yenidoğanlara HBIG ve hepatit B aşısı uygulanma durumu (20082019 yılları karş1laştırması)

\begin{tabular}{|c|c|c|c|c|c|c|}
\hline \multicolumn{7}{|c|}{ HBsAg testi yapılma durumu } \\
\hline & Yapılmış & $\%$ & Yapılmamış & $\%$ & $\mathrm{X}^{2}$ & $p$ \\
\hline $2008 *$ & 18254 & 99,9 & 24 & 0,1 & 42,3 & 0,001 \\
\hline 2019 & 32082 & 100,0 & 0 & 0,0 & & \\
\hline \multicolumn{7}{|c|}{ HBsAg durumu } \\
\hline & Pozitif & $\%$ & Negatif & $\%$ & $\mathrm{X}^{2}$ & $p$ \\
\hline $2008 *$ & 866 & 4,7 & 17412 & 95,3 & 92116.1 & 0,001 \\
\hline 2019 & 378 & 1,2 & 31704 & 98,8 & & \\
\hline \multicolumn{7}{|c|}{ HBIG uygulama durumu } \\
\hline & ulanmış & $\%$ & Uygulanmamış & $\%$ & $\mathrm{X}^{2}$ & $p$ \\
\hline $2008^{*}$ & 511 & 59,1 & 355 & 40,9 & 191,8 & 0,001 \\
\hline 2019 & 327 & $100,0 * *$ & 0 & 0,0 & & \\
\hline \multicolumn{7}{|c|}{ Hepat B aşısı uygulama durumu } \\
\hline & ulanmış & $\%$ & Uygulanmamış & $\%$ & $\mathrm{X}^{2}$ & $p$ \\
\hline $2008^{*}$ & 16212 & 88,7 & 2066 & 11,3 & 4559,7 & 0,001 \\
\hline 2019 & 31273 & $100,0 * *$ & 0 & 0,0 & & \\
\hline
\end{tabular}

*2008 yılı verileri Koruk ve arkadaşlarının yaptıkları çalışmadan alınmıştır. ${ }^{5}$

** Daha önce açıklanan uygun tıbbi gerekçelerle HBIG ve Hepatit B aşısı uygulanamayanlar göz ardı edilmiştir.

\section{Tartışma}

Hepatit B virüs enfeksiyonunun global prevalansının 2015 yılında \%3,5, Afrika'da $\% 6,1$ ve Bat1 Pasifik Bölgesi'nde \%6,2 olduğu ve dünyada ortalama 257 milyon kişinin Hepatit B virüs enfeksiyonu ile yaşadığı DSÖ tarafından bildirilmiştir. Dünya popülasyonunun \%25,3'ünün doğurganlık çağındaki kadınların oluşturduğu düşünülürse, doğurganlık çağındaki 65 milyon kadın hastanın bu etkeni bebeklerine bulaştırma potansiyeli bulunmaktadır. ${ }^{14} \mathrm{Bu}$ durumun önemi Şanlıurfa'da yapılan araştırmalarda da belirtilmektedir. Araştırmalarda 'Ailede hepatit B bulunmas1' toplumda \%7,7, berberlerde $\% 11,6, \quad$ ağız-diş sağlığı çalışanlarında \%15,6 olarak saptanmıştır ve HBsAg pozitiflerde negatiflere göre anlamlı fark yaratan tek değişken olarak yer almıştır. ${ }^{6}$, 15, $16 \mathrm{Bu}$ değișken her ne kadar horizontal bulaşı işaret ediyor gibi görünse de düzenli gebe taramalarının bu araştırmalardan daha sonraki yıllarda başladığı, dolayısı ile bu değişkenin içinde anneden bebeğe perinatal bulaşın da önemli yer tuttuğu tahmin edilmektedir. Nitekim, Harran Üniversitesi Tıp Fakültesinde takip edilen çocuk yaşta kronik hepatit B hastalarının \%64,2'sinin ailesinde HBV enfeksiyonu öyküsü bulunduğu ve \%56,7'sinin annesinde HBsAg pozitif olduğu belirtilmektedir. ${ }^{17}$

Annesi hepatit B taşıyıcısı olan bebeğe hepatit B aşısı ve HBIG uygulanması ile çocuklar arasında kronik hepatit B enfeksiyonunun insidansinda ve prevalansında önemli bir azalma sağlandığ bilinmektedir. ${ }^{18,19}$

Çalışmada, hastaneye başvuran tüm gebelerin \%80,8'ine, hastanede doğum yapanların ise tamamina $(\% 100,0)$ HBsAg testi yapılmıştır. 2008 yılında geliştirme müdahalesi ile yakalanan yüksek tarama düzeyi devam ettiği gözlenmektedir. Öte yandan, hastaneden sağlık hizmeti alan ancak doğum yapmayan yaklaşı 10 bin gebeye test yapılmamıştır. Taramaların bu kadar 
yükseldiği bir dönemde bu grubun başka bir hekim ya da aile hekimi tarafindan test yapılmış olma ihtimali de çok yüksektir. Gebelerde Hepatit B taramasındaki bu artışta, ülkemizde doğumların büyük bir kısmının sağlık merkezlerinde ve doktor takibinde yapılıyor olmasının, güncellenen sağlık programlarının ve mevzuatın da etkisi büyüktür. ${ }^{11,12}$ Bununla birlikte yerel ve bölgesel düzeyde yapılan müdahale çalışmalarının da katkısı olmaktadır. Nitekim çalışmanın yürütüldüğü hastanede 2007-2008 y1lları arasinda yapılan müdahale çalışmasında, müdahale öncesi $\mathrm{HBsAg}$ testi yapılma düzeyinin \%16,5 iken, müdahale sonrası \%99,9 olduğu belirtilmektedir. ${ }^{5}$ Yine Koruk ve ark.'nın Şanlıurfa il genelinde yapmış oldukları bir müdahale çalışmasında; müdahale öncesi $\mathrm{HBsAg}$ testi yaptırma düzeyinin 2011 y1lında \%25,8 iken, 2012 y1lında \%61,8 ve 2013 y1lında ise \%77,9'a yükseldiği belirtilmektedir. ${ }^{20}$ Birçok ülkede yapılan farklı müdahale çalışmalarında da benzer şekilde, müdahale sonrası test yapma/yaptırma düzeylerinde artış olduğu gösterilmiştir. ${ }^{21-23}$

Aynı hastanede 2008 y1lında HBsAg pozitiflik düzeyinin $\% 4,7$ olduğu, daha sonra Çopur Çiçek ve arkadaşları 2007-2009 döneminde \%3,6 olarak saptadıkları belirtmektedirler. ${ }^{24}$ Koruk ve arkadaşlarının tüm Şanlıurfa müdahalesinde ise, 2011'den 2013'e doğru HBsAg düzeyinin gebelerde $\% 2,5$ 'ten $\% 1,4$ 'e düştüğü gözlenmiştir. ${ }^{19} \mathrm{Bu}$ çalışmada elde edilen \%1,2 HBsAg pozitiflik düzeyi ile 11 yıl içerisinde yaklaşık \%75'lik bir düşüş olduğu görülmektedir. 2007 yılında yayınlanan bir metaanalizde, Türkiye' de gebe kadınlarda HBsAg pozitifliği \%3,5 ile \%9,3 arasında gösterilirken, 2013 yılında yayınlanan başka bir metaanalizde \%1,9-\%9,4 arasında belirtilmekte olup, alt sinırının düştüğü gözlenmektedir. ${ }^{25,26}$ Tüm bu sonuçlar, gebelerde HBsAg pozitiflik düzeylerinde azalma olduğuna işaret etmektedir. Ülkelerin gelişmişlik düzeyleri ve sağlık sistemleri ile ilgili olarak farklılıklar göstermekle birlikte, yapılan çalışma sonuçları küresel olarak da gebelerde HBsAg pozitiflik düzeylerinde azalma olduğunu göstermektedir. ${ }^{27} \mathrm{Bu}$ sonuçlarda ülkede yürütülmekte olan Hepatit
B kontrol programı, Doğum Öncesi Bakım İzlemi Programı, Genişletilmiş Bağışıklama Programı gibi korumaya yönelik ulusal programların ve yerelde yürütülen müdahale çalışmaları, hizmet içi eğitimler, halk eğitimleri ve medya etkisi gibi pek çok faktörün toplam etkisinden bahsetmek mümkündür.

\section{Sonuç}

$\mathrm{Bu}$ araştırmada, uygun tıbbi gerekçelerle yapılmayanlar hariç HBsAg testi pozitif annelerin bebeklerinin tamamina (\%100) HBIG ve hepatit B aşısı yapılmıştır. 2008 yılı sonuçları ile kıyaslandığında HBIG ve hepatit B aşısı uygulamasında önemli düzeyde artış olduğu gözlenmektedir. $\mathrm{Bu}$ başarının sağlanmasında Genişletilmiş Bağışıklama Programı'nın önemi unutulmamalıdır. ${ }^{11} \mathrm{Bu}$ programlar, çocuklarda aşılama düzeyini yükseltirken, hepatit B taramalarının daha geniş bir grupta yapılmasını ve doğumların sağlik kuruluşlarına yönlendirilmesini de sağlamaktadır. Yine, nüfusun kayıt altında olmasi da bu programların uygulamadaki başarısını arttırmaktadır. Ancak, kaçakları önlemek için hastaneye başvuran tüm gebelere doğum yapmasa dahi bu testin uygulanması için gerekli çalışmalar yapilmalidir.

\section{Araştırmanın Etik Boyutu}

Çalışma için, İlgili Üniversitenin Tıp Fakültesinin Etik Kurulu'ndan ve verilerin toplandığ1 hastaneden yazılı izni alınmıştır. Helsinki İlkeler Deklarasyonuna uygun olarak çalışılmıştır.

\section{Bilgilendirilmiş Onam}

Çalışma için hastanenin 2019 yılına ait sağlık kayıtları kullanıldığından, verilerin toplandığı hastaneden yazılı izin alınmıştır.

\section{Yazar Katkıları}

Fikir: İ.K. Tasarım: B.B., İ.K., E.Ö. Kaynakların toplanması ve/veya işlemesi: E.Ö., B.B. Analiz ve/veya yorum: B.B. Literatür taraması: F.K., B.B. Yazıyı yazan: B.B., F.K. Eleştirel inceleme: F.K., İ.K.

\section{Teşekkürler}


Araştırmada verileri kullanılan hasta ve hasta yakınlarına bilimsel katkıları için teșekkür ederiz.

\section{Çıkar Çatıșması Beyanı}

Yazarların çıkara dayalı herhangi bir ilişkileri yoktur.

\section{Araştırma Desteği}

Araştırmanın herhangi bir destekçi kişi ya da kuruluşu yoktur.

\section{Beyanlar}

Araştırma daha önce herhangi bir bilimsel toplantıda sunulmamıştır.

\section{Hakem Değerlendirmesi}

\section{Dış bağımsız.}

\section{Kaynaklar}

1. WHO. WHO urges countries to invest in eliminating hepatitis. https://www.who.int/news-room/detail/26-07-2019-who-urgescountries-to-invest-in-eliminating-hepatitis 08.04.2020'de erişildi.

2. WHO. Hepatitis B. https://www.who.int/en/news-room/factsheets/detail/hepatitis-b 08.04.2020'de erişildi.

3. Tozun N, Ozdogan O, Cakaloglu Y, Idilman R, Karasu Z, Akarca U ve ark. Seroprevalence of hepatitis B and C virus infections and risk factors in Turkey: a fieldwork TURHEP study. Clin Microbiol Infect 2015;21:1020-1026.

4. Toy M, Önder FO, Wörmann T, Bozdayi AM, Schalm SW, Borsboom GJ ve ark. Age-and region-specific hepatitis B prevalence in Turkey estimated using generalized linear mixed models: a systematic review. BMC Infect Dis 2011;11:337.

5. Koruk I, Tekin Koruk S, Cicek Copur A, Simsek Z. An intervention study to improve $\mathrm{HBsAg}$ testing and preventive practice for hepatitis $\mathrm{B}$ in an Obstetrics Hospital. TAF Preventive Medicine Bulletine 2011; 10, 287-292.

6. Tekin Koruk S, Koruk I, Gürsoy B, Calıșır C, Yüksel F, Yıldız Zeyrek F ve ark. Hepatitis B And Hepatitis C Seroprevalance In Center Of Sanliurfa Province From Souteastern Anatolia Region And Related Risk Factors, Trakya Univ Tip Fak Derg 2010; 27, 367-372.

7. Wasmuth JC. Hepatitis B- Epidemiology, transmission and natural history. In Mauss S, Berg T, Rockstroh J, Sarrazin C, Wedemeyer H, (eds). Hepatology. Dusseldorf: Flying Publisher; 2009: 25-48.

8. TC Sağlık Bakanlığı. Genişletilmiş bağışıklama programı genelgesi http://www.saglik.gov.tr/TR/belge/13929/genisletilmisbagisiklamaprogrami-genelgesi.html. 07.04.2020'de erişildi.

9. Sağlık Bakanlığı, Türkiye Viral Hepatit Önleme ve Kontrol Programı 2018-2023. https://hsgm.saglik.gov.tr/depo/birimler/Bulasici-hastaliklardb/duyurular/Turkiye_Viral_Hepatit_Onleme_ve_Kontrol_Pro grami/Turkiye_Viral_Hepatit_Onleme_ve_Kontrol_Programi_ TR.pdf?sa=X\&ved=2ahUKEwi0m7Kl-

PDmAhVCiqQKHQZJDecQFjAGegQIBhAB. 07.07.2020'de erişildi.

10. Centers for Disease Control (CDC) Postexposure prophylaxis of hepatitis B. MMWR Morb Mortal Wkly Rep 1984, 33:28590.

11. TC Sağlık Bakanlığı. Doğum öncesi bakım yönetim rehberi 2014

[Online]. http://sbu.saglik.gov.tr/Ekutuphane/kitaplar/dogumonubakim.p df 07.04.2020'de erişildi.

12. Türkiye Nüfus ve Sağlı Araștırması 2018. http://www.hips.hacettepe.edu.tr/tnsa2018/rapor/TNSA2018_an a_Rapor.pdf 07.04.2020'de erişildi.
13. Türkiye İstatistik Kurumu TÜIK 2018 , http://www.tuik.gov.tr/PreHaberBultenleri.do?id=30696 17.07.2020'de erişildi.

14. Guidelines for the prevention, care and treatment of persons with chronic hepatitis B infection. Geneva: World Health Organization; March 2015. http://apps.who.int/iris/bitstream/10665/154590/1/97892415490 59_eng. 16.07.2020'de erişildi.

15. Koruk İ, Tekin Koruk S, Gürsoy B, Calışır C, Yüksel F, Yıldız Zeyrek $F$ ve ark. Şanliurfa İl Merkezindeki Berber ve Kuaförlerde HBV ve HCV Seroprevalansı ve Risk Faktörleri. Viral Hepatit Dergisi, 2008; 13, 97-102.

16. Tekin Koruk S, Koruk İ, Şahin M, Duygu F. Şanlıurfa'da Ağız ve Diş Sağlığı Kurumlarında Calışan Diș Hekimleri ve Diğer Personelde HBsag, Anti HBs ve Anti HCV Pozitifliğinin Değerlendirilmesi. KLIMIK Dergisi 2009; 22, 55-61.

17. Tekin Koruk S, Duygu F, Karaağaç L, Koruk İ, Çakmak A, Sırmatel F. Harran Üniversitesi Tıp Fakültesi Hastanesinde 2005-2009 Yılları Arasında Takip Edilen Cocuk Kronik Hepatit B Hastalarının Özelliklerinin İncelenmesi. Viral Hepatit Dergisi 2010; 16, 87-92.

18. Yonghao G, Jin X, Jun L, Pumei D, Ying Y, Xiuhong F ve ark An epidemiological serosurvey of hepatitis B virus shows evidence of declining prevalence due to hepatitis B vaccination in central China. Int J Infect Dis 2015;40:75-80.

19. Wasley A, Kruszon-Moran D, Kuhnert W, Simard EP, Finelli L, McQuillan G ve ark. The prevalence of hepatitis B virus infection in the United States in the era of vaccination. J Infect Dis 2010;202(2):192-201.

20. Koruk İ, Tekin S, Koruk F, Havlioğlu S, Öncül M, Ağar M ve ark. Doğum öncesi HBsAg testi yapılma oranını arttırmaya yönelik bir çalışma: Şanlıurfa deneyimi. Mersin Univ Sağlık Bilim Derg 2017;10(1); 36-44.

21. Bastani R, Glenn BA, Maxwell AE, Jo AM, Herrmann AK Crespi $\mathrm{CM}$ ve ark. Cluster-Randomized Trial to Increase Hepatitis B Testing among Koreans in Los Angeles. Cancer Epidemiol Biomarkers Prev 2015; 24(9): 1341-1349. doi: 10.1158/1055-9965.EPI-14-1396.

22. Chen MS Jr, Fang DM, Stewart SL, Ly MY, Lee S, Dang JH ve ark. Increasing hepatitis B screening for hmong adults: results from a randomized controlled community-based study. Cancer Epidemiol Biomarkers Prev 2013; 22(5):782-91.

23. Hsu L, Bowlus CL, Stewart SL, Nguyen TT, Dang J, Chan B ve ark. Electronic messages increase hepatitis B screening in atrisk Asian American patients: a randomized, controlled trial. Dig Dis Sci 2013;58(3):807-14.

24. Çiçek AÇ, Duygu F, İnakçı İH. Şanlıurfa İlinde Kadın Hastalıkları ve Doğum Hastanesine Başvuran Kadınlarda Hepatit B ve Hepatit C Seroprevalansı: Üc- Yıllık Değerlendirme. Viral Hepatit Dergisi 2012; 18(1): 15-8.

25. Mistık R. Türkiye'de viral hepatit epidemiyolojisi - Yayınların irdelenmesi, "Tabak F, Balık İ, Tekeli E (eds). Viral Hepatit", p.9-50, Viral Hepatitle Savaşım Derneği Yayını, İstanbul Medikal Yayıncılık, İstanbul; 2007.

26. Tosun S. Türkiye'de viral hepatit B Epidemiyolojisi-Yayınların Metaanalizi, "Tabak F, Tosun S (eds). Viral Hepatit", p.25-81, Viral Hepatitle Savaşım Derneği Yayını, İstanbul Medikal Yayıncılık, İstanbul; 2013.

27. Lao TT, Sahota DS, Law L-W, Cheng YKY, Leung T-Y. Agespecific prevalence of hepatitis $B$ virus infection in young pregnant women, Hong Kong Special Administrative Region of China. Bull World Health Organ 2014;92:782-789| doi: http://dx.doi.org/10.2471/BLT.13.133413. 